\title{
The Dorsal Scapular Artery - A Proposed Term for the Artery to the Rhomboid Muscles
}

\author{
DONALD F. HUELKE \\ Department of Anatomy, The University of Michigan, Medical School, \\ Ann Arbor, Michigan
}

The terminology of the arterial supply to the rhomboid and trapezius muscles is quite confusing in that each artery has been given two different names; names which are related to the variations in the origin of these vessels. According to the recent Paris Revision of the terminology ('55) one of these is the transverse cervical artery, of the thyrocervical trunk, which gives rise to a superficial and a deep branch to the trapezius and rhomboid muscles respectively. When these branches arise separately, the trapezial branch is called the "superficial cervical artery" and that to the rhomboids, the "descending scapular artery." Thus, each vessel has two different names. Generally, an artery is named by the area of supply, irrespective of its origin or variations.

Within the last 4 years, two articles have been presented in the American Literature (Daseler and Anson, '59; Huelke, '58) which indicate that the artery to the rhomboid muscles arises more frequently as an independent branch of the subclavian artery than as a branch of the transverse cervical artery of the thyrocervical trunk. In most American and British texts such a separate origin is considered the variation, whereas it is described as typical in the German literature. French authors usually refer to the latter vessel as the posterior scapular artery.

Based on the fact that the two arteries more often have separate origins, and following two of the principles adopted by the International Anatomical Nomenclature Committee (Paris, '55), a modification of the terminology was suggested (Huelke, '58, '59). The modification is as follows: (1) The term transverse cervical artery be applied to that vessel which supplies the trapezius muscle (it has an origin from the thyrocervical trunk in $77.5 \%$ of sides). (2) That the artery which supplies the rhomboid muscles take the name of the nerve along with which it passes, and be designated the dorsal scapular artery. This artery arises from the second or third part of the subclavian artery, separate from the transverse cervical artery, in approximately $70 \%$ of the sides. Thus, only one term is used for each artery.

If this modification in terminology is to be accepted internationally, there must be an agreement among anatomists as to its "usual" site of origin. Only by comparing data on the origins of these arteries from various countries can this end be achieved. Therefore, it is the purpose of this report to compare the data on these vessels of cadavers in the United States with studies from other countries.

\section{DATA AND DISCUSSION}

The major sites of origin of the dorsal scapular artery are illustrated in figure 1. In this illustration it will be noted that when the dorsal scapular artery arises behind or lateral to the anterior scalene muscle, it is an independent branch of the subclavian artery. However, when it arises medial to the muscle it is one of the terminals of the transverse cervical artery.

A list of the various types of origins found in the two most recent studies is presented in table 1 . Both studies found an origin of the dorsal scapular artery from some source other than the transverse cervical artery, of the thyrocervical trunk, in approximately 7 out of 10 cases (Daseler and Anson, 68.4\% ; Huelke, 69.1\%). The differences between the two studies are minor; in the latter study an origin from the second part of the subclavian 

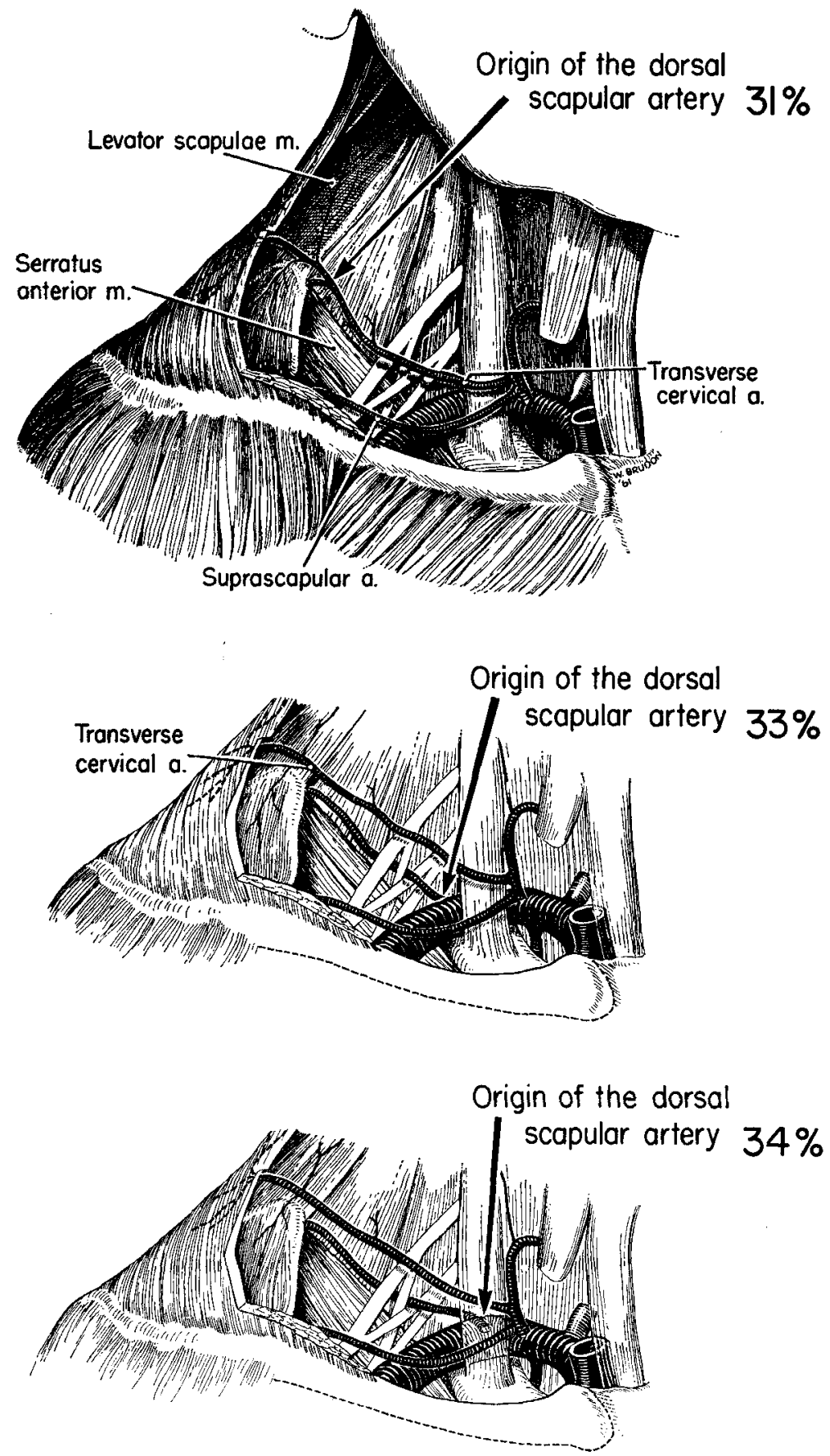

Fig. 1 Above - The origin of the dorsal scapular artery from the transverse cervical artery; this type of origin has been considered "typical" in American and British texts.

Middle - From the distal or third portion of the subclavian artery.

Below - The origin of the dorsal scapular artery from the second or scalene portion of the subclavian. 
was found in $33.6 \%$ of cases, whereas Daseler and Anson noted such an origin in $19.4 \%$. They reported an origin from the third part of the subclavian in $45.1 \%$ of cases, and I found this origin in $33.2 \%$. Rarely origins are found from other subclavian branches or directly from the axillary artery (table 1).

The various origins of the dorsal scapular artery, as found in the literature, are presented in table 2. With but few exceptions, all authors agree that the artery supplying the rhomboids arises more often from some source other than the transverse cervical artery, mainly by a vessel from the second or third part of the subclavian artery. Those in agreement on this point, however, show marked individuality in their exact site of origin. Some have a greater percentage of origin from the second part, whereas others indicate that the third part of the subclavian is the more frequent site of origin.

There are several reasons for these differences. First, there may be true differences in the origin of this vessel between the various studies. Secondly, an origin from the second or third part of the subclavian artery frequently is on, or is very near the lateral edge of the anterior scalene muscle. Therefore, what one author may call an origin from the second part of the subclavian, another investigator would record as being from the terminal part of the subclavian artery. Thirdly, viewing this origin, which is near the edge of the anterior scalene, from different angles can, at times, give different results. Finally, when the origin is directly in line with the lateral edge of the muscle it is the choice of the investigator as to whether the origin is to be recorded as lateral or behind the anterior scalene muscle.

A few studies - Deaver (1890), Thompson (1891), and Adachi ('28) - indicate that the dorsal scapular artery arises more frequently as a branch of the transverse cervical artery. Two of these studies Thompson's, and Adachi's - indicate that origins from the transverse cervical artery, approximates the $50 \%$ level $(49.3 \%$ and $46.2 \%$ respectively). Thus, both of these reports indicate only that an origin from the transverse cervical artery or from the subclavian artery directly occurs with equal frequency.

In a brief note, Deaver (1890) reported that this vessel arose almost always from the transverse cervical artery (98.2\%). His results are so atypical when compared with the entire group that his results are questionable.

TABLE 1

The origin of the dorsal scapular artery as found in the two most recent studies

\begin{tabular}{|c|c|c|c|}
\hline & Origin & $\begin{array}{l}\text { Daseler and Anson } \\
765 \text { sides }\end{array}$ & $\begin{array}{c}\text { Huelke } \\
178 \text { sides }\end{array}$ \\
\hline (A) & From transverse cervical artery (of thyrocervical trunk) & $\begin{array}{c}\% \\
31.6\end{array}$ & $\begin{array}{c}\% \\
30.9\end{array}$ \\
\hline (B) & $\begin{array}{l}\text { From Subclavian II } \\
\text { Directly } \\
\text { With costocervical trunk } \\
\text { With suprascapular artery }\end{array}$ & $\begin{array}{r}18.2 \\
1.0 \\
0.2\end{array}$ & $\begin{array}{r}30.3 \\
1.1 \\
2.2\end{array}$ \\
\hline (C) & $\begin{array}{l}\text { From Subclavian III } \\
\text { Directly } \\
\text { With costocervical trunk } \\
\text { With suprascapular artery }\end{array}$ & $\begin{array}{r}42.3 \\
0.2 \\
2.6\end{array}$ & $\begin{array}{r}30.9 \\
0.6 \\
1.7\end{array}$ \\
\hline (D) & $\begin{array}{l}\text { Other origins: } \\
\text { Subclavian I } \\
\text { Axillary I } \\
\text { Axillary II } \\
\text { Internal thoracic art. } \\
\text { Thyroid ima art. (of aorta) } \\
\text { With suprascapular art. of subclavian I. } \\
\text { With costocervical trunk of subclavian } \mathrm{I} \text {. }\end{array}$ & $\begin{array}{l}3.1 \\
1.2 \\
\overrightarrow{0.8} \\
0.1 \\
1.6 \\
0.8\end{array}$ & $\begin{array}{l}0.6 \\
1.2 \\
0.6 \\
- \\
- \\
-\end{array}$ \\
\hline Origir & n other than the transverse cervical artery & 68.4 & 69.1 \\
\hline
\end{tabular}




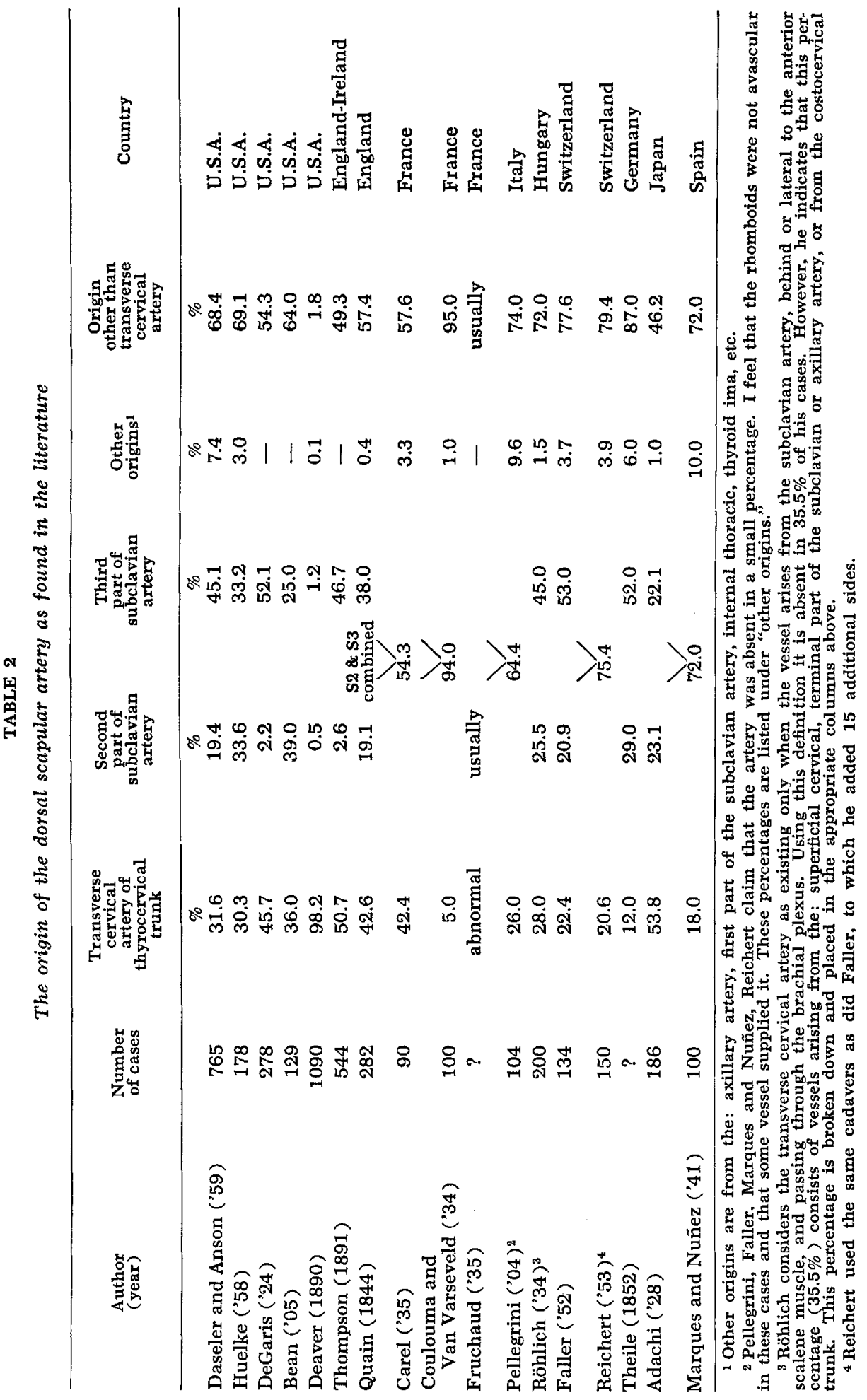


The dorsal scapular artery passes through the brachial plexus either above or below the middle trunk to reach the levator scapulae muscle near the superior angle of the scapula where it joins the dorsal scapular nerve. All authors agree that this is the region of passage in the majority of cases. When this vessel is a branch of the transverse cervical artery however, it always passes over the brachial plexus. Together the artery and nerve pass downward near the scapular attachment of the rhomboid muscles; throughout this course the artery supplies the rhomboid muscles by multiple small branches and by a larger branch, the lower part of the trapezius muscle.

\section{SUMMARY}

Confusing terminology exists with regard to the vasculature of the trapezius and rhomboid muscles, for the names of the arteries supplying these muscles vary according to the variation in origin of these vessels. To alleviate this confusion, the term "dorsal scapular" has been proposed for that artery which supplies the rhomboid muscles. The transverse cervical artery then, is the supply of the trapezius muscle. These arteries are so named irrespective of their site of origin.

The studies of investigators in the U.S.A., France, Germany, Italy, Hungary, Switzerland, and Spain agree that the arterial supply to the rhomboid muscles the dorsal scapular artery - originates preponderantly from some source other than the transverse cervical artery. Two studies indicate that the vessel arises either directly from the subclavian artery or as a branch of the transverse cervical artery with equal frequency. Only one report has presented data which showed that the transverse cervical artery is more frequently the site of origin of the artery to the rhomboid muscles.

\section{LITERATURE CITED}

Adachi, B. 1928 Das Arteriensystem der Japaner. Bd. 1, Kyoto.

Bean, R. 1905 A composite study of the subclavian artery in Man. Am. J. Anat., 4: 303378.

Carel, H. 1935 Etude morphologique suc l'origine, le trajet et le mode de ramescence de l'autère sous-clavière. Thèse med. Bordeaux.

Coulouma, P., and F. Van Varseveld 1934 Les branches de l'àrtere sous-clavière et leurs variations. Echo méd. Nord., 2: 260-281.

Daseler, E. H., and B. J. Ánson 1959 Surgical anatomy of the subclavian artery and its branches. Surg. Gynec. Obst., 108: 149-174.

Deaver, J. B. 1890 Anomalies of the Posterior Scapular Artery. Penn. U. Med. Mag., 2: 151.

DeGaris, C. 1924 Patterns of branching of the subclavian artery in White and Negro stocks. Amer. J. Phys. Anthrop., 7: 94-107.

Faller, A. 1952 Statistische Untersuchungen über Ursprung and Kaliber der arteria transversa colli bein Menschen. Untersuchung an 134 Halshälften. Arch. f. Kriesl.-Forsch., 18: 161-167.

Fruchaud, H. 1935 Etude anatomo-churgicale des vaisseaux scapularires postérieurs. Ann. anat. path., 12: 143-156.

Huelke, D. F. 1958 A study of the transverse cervical and dorsal scapular arteries. Anat. Rec., 132: 233-245.

1959 The transverse cervical and dor sal scapular arteries. Ibid., 133: 289.

Kagi, J. 1959 Beitrag zur Topographie der arteria transversa colli, Eine Untersuchung an 134 Hälshalften. Anat. Anz., 107: 168-186.

Marques, J. M., and A. Nuñez 1941 Contribucion al conocimiento de las disposiciones arteriales y nerviosas preescalénicas. Arch. esp. Morfol,, 1: 11-104.

Pellegrini, A. 1906 Le arteriae subclavia e axillaris nell'uomo studiate col metodo statistico. Arch ital. Anat. Embriol., 5: 205-255, 466-505.

Quain, R. 1844 Anatomy of the Arteries of the Human Body. Taylor and Walton, London, $555 \mathrm{p}$.

Reichert, P. 1952 Der truncus thyreocervicalis, untersuchung an 150 hälshalften. Inaugural Diss. Zürich.

Röhlich, K. 1934 tbber die arteria transversa colli des Menschen. Anat. Anz., 79; 27-53.

Theile 1852 As found in Faller, A., Arch. $f$. Kries., 18: 161-167.

Thompson, A. 1891 Second annual report of the Committee of Collective Investigation of the Anatomical Society of Great Britain and Ireland for the year 1890-1891. J. Anat. Physiol., 26: 77-80. 